\section{A Crossover Study Comparing In-Plane and Out- of-Plane Approaches for Simulated Ultrasound- Guided Central Venous Cannulation on Phantom Models by Anaesthesiology Trainees}

\author{
YAP KB ${ }^{1}$, SHEREEN TSP ${ }^{2}$, YEOH CN ${ }^{3}$, LIU CY ${ }^{3}$, NADIA $\mathrm{MN}^{3}$,

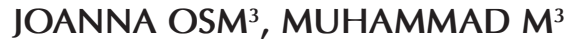 \\ ${ }^{1}$ Department of Anaesthesiology, Tuanku Ampuan Najihah, Ministry of Health Malaysia, \\ Kuala Pilah, Negeri Sembilan, Malaysia \\ ${ }^{2}$ Faculty of Medicine and Health Sciences, Universiti Tunku Abdul Rahman, Jalan Sungai \\ Long, Bandar Sungai Long, 43200, Kajang, Selangor, Malaysia. \\ ${ }^{3}$ Department of Anaesthesiology \& Intensive Care, Faculty of Medicine, Universiti \\ Kebangsaan Malaysia Medical Centre, Jalan Yaacob Latif, Bandar Tun Razak, 56000 \\ Cheras, Kuala Lumpur, Malaysia.
}

\begin{abstract}
ABSTRAK
Kajian bersilang kumpulan ini dijalankan untuk membandingkan insiden penembusan dinding belakang vena fantom di antara teknik in-plane' (IPA) dan 'out-of-plane' (OPA) semasa pemasangan kateter vena pusat dengan panduan ultrasound di kalangan doktor pelatih bius. Model fantom sebagai model simulasi vena dan arteri pusat dicucuk oleh 37 orang doktor pelatih bius menggunakan kedua-dua teknik tersebut. Jumlah keseluruhan masa prosedur dan masa yang diambil dari permulaan pengimbasan imej sehingga permulaan penusukan jarum dicatat. Bilangan nombor percubaan sehingga vena berjaya ditusuk juga dikira. Akhirnya, semua model diperiksa untuk kejadian penembusan dinding belakang vena dan penembusan arteri. Jumlah kesuluruhan masa prosedur adalah lebih singkat untuk teknik OPA (26.5 vs 50.3 saat, $p=0.001$ ). Masa yang diambil dari permulaan pengimbasan imej sehingga permulaan pencucukan jarum adalah lebih singkat untuk teknik OPA (2.2 vs 12.3 saat, $p<0.0001)$. Teknik IPA memerlukan percubaan penembusan lebih banyak yang ketara. Dua puluh dan sebelas peserta berjaya dalam percubaan pertama untuk teknik-teknik OPA dan IPA, masing-masing $(p=0.034)$. Tiada perbezaan wujud dalam kejadian penembusan dinding belakang vena di antara kedua-dua teknik. Teknik OPA melibatkan kurang penembusan arteri berbanding dengan teknik IPA (2 vs 9, p=0.022). Kejadian penembusan dinding belakang vena pusat semasa panduan ultrasound dengan menggunakan
\end{abstract}

Address for correspondence and reprint requests: Dr. Muhammad Maaya. Department of Anaesthesiology \& Intensive Care, Faculty of Medicine, Universiti Kebangsaan Malaysia Medical Centre, Jalan Yaacob Latif, Bandar Tun Razak, 56000 Cheras, Kuala Lumpur, Malaysia. Tel: +603-9145 7359 Email: muhammad@ ppukm.ukm.edu.my/mm0427@gmail.com 
teknik IPA dan OPA di kalangan doktor pelatih bius adalah setara.

Kata kunci: "in-plane", "out-of-plane", penembusan salur darah bawah panduan ultrasound, pelatih, simulasi

\begin{abstract}
This prospective crossover study compared the incidence of posterior vessel wall puncture between two approaches during ultrasound-guided simulated central venous cannulation by anaesthesiology trainees. Each phantom model, simulating a central vein and artery, was cannulated by 37 anaesthesiology trainees under ultrasound-guidance using the in-plane approach (IPA) and out-of-plane approach (OPA). Total procedural time and the time taken from starting image scanning until commencing puncture, was recorded. The number of attempts required to achieve successful venous cannulation was noted. Finally, the models were examined for posterior venous wall and arterial puncture. Total procedural time was shorter with the OPA (26.5 vs 50.3 seconds, $p=0.001$ ). The time taken from starting image scanning until commencing puncture was shorter for the OPA (2.2 vs 12.3 seconds, $p<0.0001)$. The IPA resulted in significantly more attempts for cannulation. Twenty and eleven participants were successful within the first pass using the OPA and IPA, respectively $(p=0.034)$. There was no difference in the incidence of posterior vessel wall puncture between these two techniques. The OPA resulted in less arterial puncture compared to the IPA ( 2 vs $9, p=0.022)$. The incidence of posterior vessel wall puncture between the IPA and OPA during ultrasound-guided simulated central venous cannulation by anaesthesiology trainees was comparable.
\end{abstract}

Keywords: in-plane, out-of-plane, ultrasound-guided cannulation, simulation, trainee

\section{INTRODUCTION}

Ultrasound-guided central venous catheterisation has gained popularity over the anatomical landmark technique in the past 30 years, as the former has shown higher first attempt success rates, shorter procedural time and fewer procedure-related complications, such as adjacent tissue injury and pneumothorax (Hind et al. 2003; Wu et al. 2013). As a result, central venous cannulation performed under ultrasound guidance was recommended in several national guidelines (Lamperti et al. 2012; NICE 2002; Troianos et al. 2012).

There are two main approaches to ultrasound-guided central venous access, of which, the more popular and favoured approach among novice ultrasound users is the out-ofplane (OPA) approach. In the OPA, the ultrasound transducer is placed perpendicular to the length of the target vein and the midpoint of the 
transducer serves as the reference point for needle insertion (Blaivas et al. 2003). In this technique, only the cross section image of the needle is seen on the ultrasound window and there is a high tendency to lose track of the tip of the needle. This may lead to a theoretically higher risk of accidental puncture of neighbouring arteries, injury to surrounding structures, or double vessel wall puncture, whereby the tip of the needle passes through the vein via the posterior wall. In a study using phantom models, a $64 \%$ incidence of posterior vessel wall puncture was reported when novices performed cannulation utilising the OPA (Blaivas \& Adhikari 2009).

For the in-plane approach (IPA), the transducer is placed in-line to the axis of both the target vessel and needle, allowing better visualisation of the needle tip and shaft as the needle is advanced into the tissue (Ball et al. 2012). This technique is less popular among novice ultrasound users due to higher technical difficulty, longer procedural time and a steeper learning curve for proficiency (Blaivas et al. 2003). Some studies reported higher first attempt success rates for cannulation, and lower incidences of posterior vessel wall puncture with the IPA compared to the OPA, although this difference was not statistically significant (Ball et al. 2012; Moon et al. 2010).

In this study, we aimed to determine whether ultrasound-guided central venous cannulation using the IPA has a lower incidence of posterior vessel wall puncture compared to the OPA among trainees in anaesthesiology using phantom models.

\section{MATERIALS AND METHODS}

This prospective crossover study was conducted at the Department of Anaesthesia and Intensive Care, Hospital Kuala Lumpur (HKL), following approval by the Research Committee, Department of Anaesthesiology \& Intensive Care, Universiti Kebangsaan Malaysia Medical Centre (UKMMC) (registration number: FF-2015-061), and Medical Research \& Ethics Committee (registration number: NMRR-14-157823845(IIR)) under Ministry of Health, Malaysia.

All anaesthesiology trainees in the Department of Anaesthesia and Intensive Care, HKL, with or without prior experience in either approaches of ultrasound-guided central venous cannulation, were eligible to participate in the study. Any trainee who refused to participate was excluded.

Chicken breast pieces and dyefilled tubular balloons were used to simulate soft tissue and blood vessels, respectively. To ensure uniformity, all phantom models were personally put together by the investigator. Each phantom unit consisted of two pieces of halal chicken breasts, with thickness standardised at 1.5 to $2 \mathrm{~cm}$. The phantom vessels were placed centrally and next to each other between the two pieces of chicken breasts which were adequately thawed to room temperature. Two tubular balloons of different sizes were filled with different coloured dyes; the 8-mm diameter balloon was filled with blue dye to simulate a vein, while the $6-\mathrm{mm}$ 
diameter balloon was filled with red dye to represent an artery. All balloons were filled-up to the respective diameter without overdistension. The phantom vessels were tied at the open ends after they were filled with the dye, with care taken to avoid air bubble entrapment within. In order to ensure that the different components stay in place, the phantom units were compressed tightly and held together with pins. Lastly, ultrasound imaging was performed on each unit to check the simulated vessels' positions and there was absence of trapped air bubble. The phantom unit was placed such that the simulated vein was to the right of the artery, which mimicked the anatomical arrangement of the right internal jugular vein in relation to the right carotid artery.

There were four sessions of the study period; each session comprising of eight to ten participants. For all sessions, a consultant anaesthesiologist experienced in ultrasound-guided central venous cannulation delivered a lecture and performed cannulation of both approaches on the phantom unit. Then, the participants received didactic training for 20 minutes supervised by the consultant anaesthesiologist.

A single linear probe of $13-6 \mathrm{MHz}$ frequency, attached to a dedicated ultrasound machine (SonoSite M-Turbo ${ }^{\circledR}$, SonoSite, Inc., Bothell, WA, USA) for this study, was used. Each participant was allocated two sets of phantom models; one for the OPA and another for the IPA. The sequence for which approach to be performed first, either OPA or IPA, was randomised by a computer-generated randomisation list. The steps for both are described below:

i) Out-of-plane technique

The participant placed the ultrasound probe perpendicular to the axis of the simulated vein. The position of the probe was adjusted until the short axis view of the vein was seen in the centre of the ultrasound machine display.

ii) In-plane technique:

The participant first located the vein using the out-of-plane technique. Once the cross-sectional image of the target vein was seen, the probe was rotated $90^{\circ}$ so that the long axis of the probe was in line to the target vein.

The participants manipulated the ultrasound probe to obtain the optimal view for each plane before attempting cannulation using an 18-gauge intravenous cannula attached to an empty 5-ml syringe. The ultrasound images of the simulated vessels and needle within the phantom model are shown in Figure 1 (IPA) and Figure 2 (OPA).

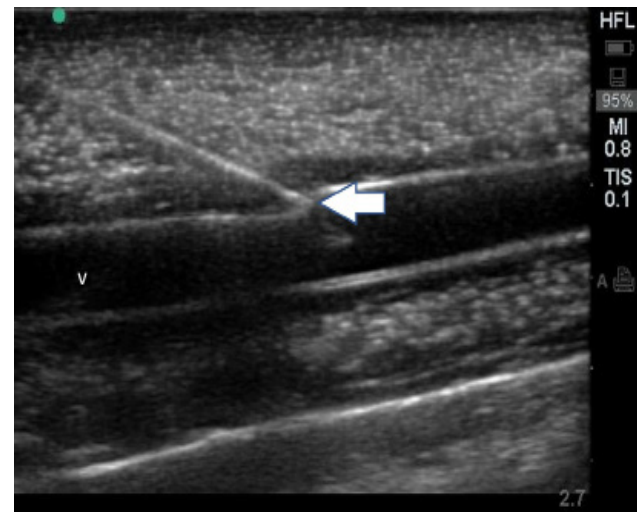

Figure 1: Ultrasonographic image of phantom vessel cannulation using the in-plane approach, with the simulated vein (v) in longitudinal view, and the needle tip (arrow) indenting the vessel wall. 


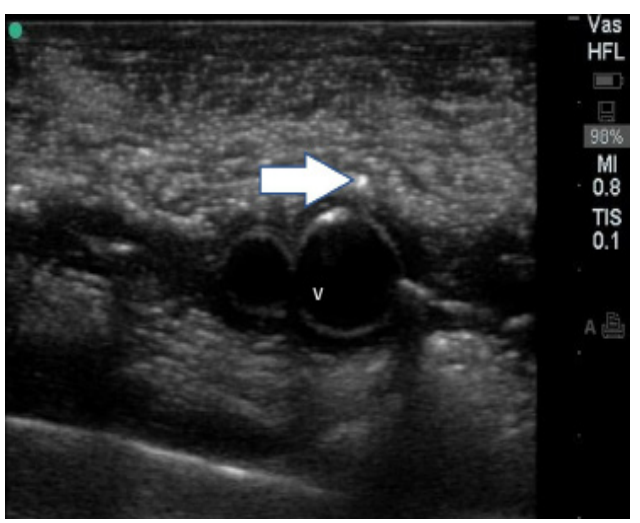

Figure 2: Ultrasonographic image of phantom vessel cannulation using the outof-plane approach, with the simulated vein (v) in transverse view and needle tip (arrow) approaching the vessel wall.

Ten minutes was given to perform each cannulation technique. After performing cannulation in one plane, each participant was given a fresh phantom model for the other approach. For each approach, the time taken (in seconds) from the beginning of image scanning until commencing needle puncture, time to successful venous cannulation, total procedural time, number of attempts, and number of accidental arterial punctures were recorded.

The time taken from the beginning of image scanning until commencing needle puncture was defined as the time from when the ultrasound probe came into contact with the surface of the phantom model, until it was pierced by the needle. A successful venous cannulation was when there was a backflow of blue-coloured dye into the syringe during cannulation. The time taken for successful venous cannulation was recorded from commencement of cannulation until successful venous cannulation. Total procedural time was taken from the time the ultrasound probe came into contact with the surface of the phantom model until successful venous cannulation. An attempt was defined as needle insertion, reinsertion or redirection without removing the needle shaft from the phantom unit.

After successful venous cannulation, the phantom units were disassembled for the vessels to be examined for any posterior venous wall puncture (double puncture of the vein) and arterial puncture. Additional fluid was injected into the balloons to demonstrate any leak from puncture defect. Subsequent participants were given new sets of phantom units, intravenous cannulae and syringes. After completing the practical sessions, the participants were asked to state their preferred ultrasonographic view, either in-plane or out-of-plane, for future cannulation.

From a previous study, the incidence of posterior vessel wall puncture during ultrasound-guided venous cannulation in phantom was $64 \%$. We considered a $50 \%$ reduction in the incidence as significant if the procedure was performed using the in-plane approach. Therefore, with $\alpha$ level of $0.05, \beta$ value of $0.80, m=1, P_{1}$ $=0.32$ and $P_{0}=0.64$, the sample size required was 37 participants for each technique, which was calculated using the PS programme version 3.0.43.

\section{RESULTS}

A total of 37 participants were recruited for this study, and the participant's demography and experience were presented in Table 1. 
Table 1: Participants' demography and experience. Values are expressed in mean \pm standard deviation, frequency (percentage) or median (interquartile range), as appropriate

\begin{tabular}{lc}
\hline & (n = 37) \\
\hline Age (year) & $31.5 \pm 1.5$ \\
Gender & \\
Male & $12(32.4)$ \\
Female & $25(67.6)$ \\
Experience in anaesthesia (year) & $4(4,5)$ \\
Prior number of experience in ultrasound-guided cannulation & $20(10,25)$ \\
\hline
\end{tabular}

The number of attempts and different time measurements were presented in Table 2. When compared to the IPA, the participants demonstrated better first pass success with the OPA, as well as significantly lesser number of attempts at cannulation $(p=0.014)$. All the participants successfully cannulated the simulated vein under ultrasoundguidance with both techniques within 210 seconds of beginning the scan, the longest being 200.7 seconds, using the IPA.

The incidence of posterior vessel wall puncture was comparable using either techniques $(p=0.102)$, as shown in Figure 3.
There was a higher incidence of arterial puncture with the IPA compared to the OPA $(p=0.022)$, as shown in Figure 4.

A total of 21 out of $37(56.8 \%)$ of the participants chose the OPA over the IPA as their preferred technique for ultrasound-guided central venous cannulation in the future.

\section{DISCUSSION}

Ultrasound-guided central venous cannulation has, in recent times, been supported by a growing number of evidence and is currently recommended by several societies'

Table 2: Time taken from image scanning until needle puncture, number of attempts, first-pass success, time for cannulation and total procedural time between in-plane and out-of-plane techniques. Values are expressed as median (interquartile range) and frequency (percentage), as appropriate.

\begin{tabular}{lccc}
\hline & In-plane & Out-of-plane & p value \\
\hline $\begin{array}{l}\text { Time taken from image scanning until } \\
\text { needle puncture (sec) }\end{array}$ & $12.3(4.0,17.9)$ & $2.2(1.5,2.9)$ & $<0.001$ \\
$\begin{array}{l}\text { Number of attempts } \\
\quad \text { (First pass success) }\end{array}$ & $11(29.7)$ & $20(54.1)$ & 0.034 \\
2 & $14(37.8)$ & $13(35.1)$ & \\
3 & $11(29.7)$ & $3(8.1)$ & \\
4 & $1(2.7)$ & $1(2.7)$ & \\
$\begin{array}{l}\text { Time taken for successful venous } \\
\text { cannulation (sec) }\end{array}$ & $39.1(22.3,75.0)$ & $24.3(13.4,46.6)$ & 0.054 \\
Total procedural time (sec) & $50.3(34.4,89.1)$ & $26.5(19.1,48.3)$ & 0.001 \\
\hline
\end{tabular}




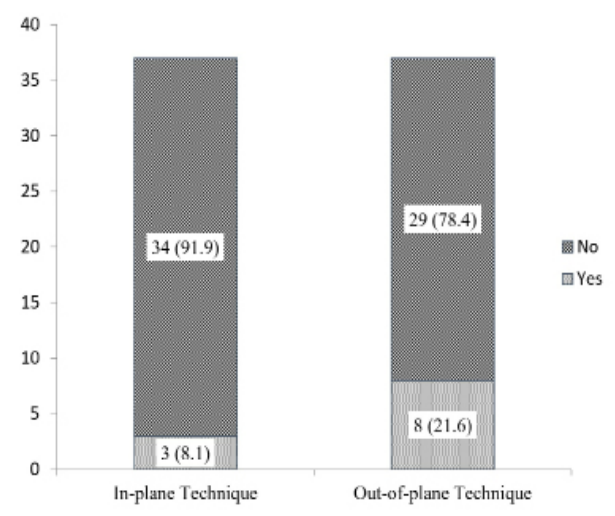

Figure 3: Incidence of posterior vessel wall puncture ( $\mathrm{n}=37$ in each group). Values are expressed as frequency (percentage).

guidelines (Lamperti et al. 2012; Troianos et al. 2012). Generally, the two most employed approaches for ultrasound-guided venous cannulation are the OPA and IPA, while a new approach, the oblique-plane technique, was proposed recently (Weiner et al. 2013).

Phantom models were utilised to investigate the risk of posterior vessel wall puncture in this study because it would be unethical and almost impossible to quantify posterior wall puncture if the study was carried out on human subjects.

The majority $(78.4 \%)$ of the participants in this study disclosed previous experience in ultrasoundguided central venous cannulation amounting to less than 25 attempts. In this study, we found that cannulation using the OPA resulted in higher firstpass success rates $(54.1 \%)$, with fewer number of attempts compared to the IPA. This finding was consistent with other studies, where the OPA was favoured by novice ultrasonography users, mainly due to the simplicity of

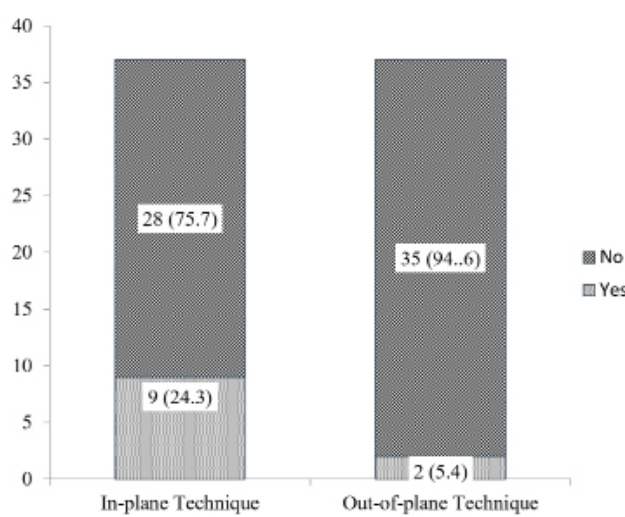

Figure 4: Incidence of accidental arterial puncture ( $\mathrm{n}=37$ in each group). Values are expressed as frequency (percentage).

the technique, shorter learning curve and faster venous cannulation (Blaivas et al. 2003; Caffery et al. 2018; Collins et al. 2013). Difficulty with the IPA could, in part, be due to the task of advancing the needle in the centre and in-line with the narrow plane of the ultrasound beam, with the operator needing to readjust his trajectory or needle entry point. Furthermore, with the IPA, the operator has to have a higher degree of operator-machine coordination to maintain the probe positioned in such a way so as to keep the plane in-line with both the target vessel and needle.

Apart from the skill needed to keep the image of the objects in-line, the IPA requires the operator to obtain the target vessel in transverse view before rotating the probe perpendicularly to visualise the target vessel in the longitudinal view (Vogel et al. 2015; Weiner et al. 2013). This additional step contributed to a longer time from image scanning until needle puncture. In our study, the participants took longer to get the optimal view prior 
to cannulation, which was similar to another study where novices were asked to cannulate commercial phantom models using these two approaches (Ball et al. 2012). However, once the optimum image of the target vessel was visualised, we found no difference in cannulation time with either techniques. Total procedural time was longer when using the IPA compared to the OPA, which was consistent with a study where residents in the emergency department were asked to cannulate gelatine models (Blaivas et al. 2003). However, a recent investigation found no difference in the total procedural time with the different approaches when performed by residents (Cafferty et al. 2018).

The OPA has frequently been reported to be associated with a higher likelihood of posterior venous wall puncture, with a reported complication rate as high as $64 \%$, due to the difficulty in tracking the needle tip while advancing the needle (Blaivas \& Adhikari 2009; Moon et al. 2010; Vogel et al. 2015). The hyperechoic, single-dot-like image seen in the OPA could not be differentiated between it being the needle shaft or the tip, hence risked inadvertent posterior vessel wall puncture (Blaivas \& Adhikari 2009). On the other hand, cannulation using the IPA showed better needle visualisation with improved precision, leading to a lower incidence of posterior vessel wall puncture. In our study, the incidence of posterior wall puncture was $21.6 \%$ and $8.1 \%$ with the OPA and in the IPA, respectively. However, this difference was not statistically significant.

Accidental arterial cannulation is one of the notorious complications of central venous cannulation and is reported to have an incidence ranging from $3.2 \%$ to $7.1 \%$ (McGee \& Gould 2003). Our study found a lower incidence of unintentional arterial puncture with the OPA compared to the IPA, at $5.4 \%$ versus $24.3 \%$ respectively. This could be because the OPA enables visualisation of both vessels, thus allowing the operator to direct the needle towards the targeted vessel. Another explanation for the accidental arterial puncture was that the adjacent artery could be mistakenly identified as the target vein as the simulated artery did not pulsate as in real life, despite the participants having been informed that the vein was situated to the right of the artery.

Slightly more than half $(56.8 \%)$ of the trainees in our study preferred the OPA. This was less compared to that in a recent investigation where the OPA was chosen as the first choice of three approaches amongst $87.5 \%$ of the residents, followed by the IPA (12.5\%) and the oblique approach (0.0\%) (Caffery et al. 2018). Apart from having both vessels in view, the OPA required lesser skill in needle manoeuvring.

There were a few limitations in this study. Although different vessel sizes placed between two organic tissue were utilised to produce some degree of face validity, defined as a simulator's realism, the phantom units in this study were not ideal replica of normal human anatomy and physiology (Alsalamah et al. 2017). There was neither arterial pulsation nor respiratory variation in the diameter of the vessels, which under clinical circumstances, would aid 
identification of the respective vessels during cannulation, particularly with the IPA. The simulated vessel has the tendency to collapse after aspiration of its content upon cannulation, which could potentially lead to unintended posterior wall puncture. The spatial relationship between the artery and accompanying vein in normal human anatomy is not invariably in the same horizontal plane and next to each other (Weiner et al. 2013). In real life, their anatomical relationship changes throughout their course, and this could further be complicated by variations. Thus, the arrangement of the simulated vessels in this study could not replicate inter-individual variation in human anatomy. The duration needed for cannulation, which served as a surrogate to the level of difficulty in performing the task, was derived from a phantom unit, hence may not accurately reflect the actual clinical setting. Although attempts were made to mimic the sonographic appearance of central vasculature embedded in biological tissue, the normal human habitus could not be reproduced. The challenge of different body habitus on ultrasound probe manipulation could not be evaluated in this study.

\section{CONCLUSION}

From this study, we concluded that there was a comparable incidence of posterior vessel wall puncture between the IPA and OPA during ultrasoundguided simulated central venous cannulation by anaesthesiology trainees.

\section{REFERENCES}

Alsalamah, A., Campo, R., Tanos, V., Grimbizis, G., Van Belle, Y., Hood, K., Pugh, N., Amso, N.. 2017. Face and content validity of the virtual reality simulator 'ScanTrainer ${ }^{\prime}$ '. Gynecol Surg 14(1): 18.

Ball, R.D., Scouras, N.E., Orebaugh, S., Wilde, J., Sakai, T. 2012. Randomized, prospective, observational simulation study comparing residents' needle-guided vs free-hand ultrasound techniques for central venous catheter access. Br J Anaesth 108(1): 72-9.

Blaivas, M., Adhikari, S. 2009. An unseen danger: frequency of posterior vessel wall penetration by needles during attempts to place internal jugular vein central catheters using ultrasound guidance. Crit Care Med 37(8): 2345-9.

Blaivas, M., Brannam, L., Fernandez, E. 2003. Shortaxis versus long-axis approaches for teaching ultrasound-guided vascular access on a new inanimate model. Acad Emerg Med 10(12): 1307-11.

Caffery, T., Jagneaux, T., Jones, G.N., Stopa, E., Freeman, N., Quin, C.C., Long, A.C., Zatarain, L., Musso, M.W. 2018. Residents' preference and performance of three techniques for ultrasound-guided central venous cannulation after simulation training. Oschner J 18(2): 14650

Collins, G.B., Fanou, E-M., Young, J., Bhogal, P. 2013. A comparison of free-hand vs laser-guided longaxis ultrasound techniques in novice users. $\mathrm{Br} J$ Radio/ 86(1029): 20130026.

Hind, D., Calvert, N., McWilliams, R., Davidson, A., Paisley, S., Beverley, C., Thomas, S. 2003. Ultrasonic locating devices for central venous cannulation: meta-analysis. BMJ 327(7411): 361.

Lamperti, M., Bodenham, A.R., Pittiruti. M., Blaivas, M., Augoustides, J.G., Elbarbary, M., Pirotte, T., Karakitsos, D., LeDonne, J., Doniger, S., Scoppettuolo, G., Feller-Kopman, D., Schummer, W., Biffi, R., Desruennes, E., Melniker, L.A., Verghese, S.T. 2012. International evidence-based recommendations on ultrasound-guided vascular access. Intensive Care Med 38(7): 1105-117.

McGee, D.C., Gould, M.K. 2003. Preventing complications of central venous catheterization. N Engl J Med 348(26): 1123-33.

Moon, C.H., Blehar, D., Shear, M.A., Uyehara, P., Gaspari, R.J., Arnold, J., Cukor, J. 2010. Incidence of posterior vessel wall puncture during ultrasound-guided vessel cannulation in a simulated model. Acad Emerg Med 17(10): 1138-41.

National Institute for Clinical Excellence. 2002. Guidance on the use of ultrasound location devices for placing central venous catheters. 
Technol Apprais Guide [TA49] https://www. nice.org.uk/guidance/ta49 [1 August 2015].

Troianos, C.A., Hartman, G.S., Glass, K.E., Skubas, N.J., Eberhardt, R.T., Walker, J.D., Reeves, S.T. 2012. Guidelines for performing ultrasound guided vascular cannulation: Recommendations of the American society of echocardiography and the society of cardiovascular anesthesiologists. Anesth Analg 114(1): 46-72.

Vogel, J.A., Haukoos, J.S., Erickson, C.L., Liao, M.M., Theoret, J., Sanz, G.E., Kendall, J. 2015. Is long-axis view superior to short-axis view in ultrasound-guided central venous catheterization? Crit Care Med 43(4): 832-9.

Weiner, M.M., Geldard, P., Mittnacht, A.J.C. 2013. Ultrasound-guided vascular access: a comprehensive review. J Cardiothorac Vasc Anesth 27(2): 345-60.

Wu, S., Ling, Q., Cao, L., Wang, J., Xu, M., Zeng, W.A. 2013. Real-time two-dimensional ultrasound guidance for central venous cannulation: a meta-analysis. Anesthesiology 118(2): 361-75.

Received: 15 Oct 2018

Accepted: 24 May 2019 